FACTA UNIVERSITATIS

Series: Linguistics and Literature Vol. 18, $\mathrm{N}^{\mathrm{o}}$ 1, 2020, pp. 97-108

https://doi.org/10.22190/FULL2001097M

Original Scientific Paper

\title{
VERB AGREEMENT WITH PREVERBAL (NON) SYNCRETIC COORDINATED SUBJECTS *
}

\author{
UDC 811.163.41'367.7
}

\author{
Ivana Mitić \\ University of Niš, Faculty of Philosophy, Serbian Department, Niš, Serbia
}

\begin{abstract}
This paper examines the effects which contribute to the agreement of the verb with only one of the conjuncts of different values for gender and number as opposed to resolved agreement. Bošković (2009) claims that resolved agreement is the only available pattern of agreement. New experimental research on a Slovenian sample (Marušič, Nevins, and Badecker 2015) confirms that a verb can agree with the plural conjunct as well. These authors, as well as Willer Gold et al. (2016) attest that agreement occurs in phonological form in Slovenian and Serbian. This study is based on an elicited production experiment and acceptability judgments experiments to verify what happens when a verb is in agreement with pre-verbal (non)syncretic coordinated conjuncts of different values for gender and number. The results indicate that resolved agreement is far less frequently used when the verb is in agreement with a syncretic coordinated subject than with a non-syncretic one, as well as that agreement with the last plural conjunct is a stable and available agreement pattern whether or not a verb is in agreement with a (non)syncretic coordinated subject. The results support the hypothesis that agreement occurs in phonological form.
\end{abstract}

Key words: agreement, coordinated subject, grammatical gender and grammatical number, syncretism, linear proximity

\footnotetext{
Submitted April 15, 2020; Accepted May 23, 2020

Corresponding author: Ivana Mitić

University of Nišs, Faculty of Philosophy

E-mail: ivana.mitic@ filfak.ni.ac.rs

* The paper is based on the unpublished doctoral dissertation I. Mitić Efekat gramatičkih $i$ semantičkih karakteristika koordiniranih subjekata na slaganje glagola u rodu u srpskom jeziku, 2019, Faculty of Philology and Arts, University of Kragujevac. Part of the results presented in this paper were already discussed in "Plural conjuncts and syncretism facilitate gender agreement in Serbo-Croatian: experimental evidence", with B. Arsenijević, available at https://www.frontiersin.org/articles/10.3389/fpsyg.2019.00942/full.
} 


\section{INTRODUCTION}

This paper examines the effects which influence the choice between resolved agreement and the agreement with only one of the conjuncts of the pre-verbal (non)syncretic coordinated subject with a first neutral gender singular conjunct and the last feminine gender plural conjunct. Previous research (Maretić 1899, Corbett 1983) lists resolved agreement - agreement in masculine gender, plural form - as the most frequently used pattern of agreement when a verb agrees with a coordinated subject consisting of conjuncts of different gender and number values. Bošković (2009) claims that agreement with one of the conjuncts of a coordinated subject with different gender and number values is not possible in the Serbian language for syntactic reasons. Recent experimental research on Slovenian language (Marušič, Nevins, and Badecker 2015) confirms that a verb can agree with a plural conjunct as well. What these authors have not examined, which is the objective of this study, is what occurs when a verb agrees with a pre-verbal (non)syncretic coordinated subject consisting of a first neutral gender singular conjunct and the last feminine gender plural conjunct.

Previous literature discusses at least two approaches to agreement. According to one, agreement is a purely syntactical mechanism which cannot be influenced by morphosyntactic and morphophonological factors (Bošković 2009). According to the approach advocated by Marušič, Nevins, and Badecker (2015) and Willer-Gold et al. (2016), linear proximity affects the choice of the last conjunct as the agreement controller, which is why, according to these authors, agreement occurs in the phonological form as well. If we take into account the fact that agreement is influenced by factors such as the linear order of elements and that the process of agreement occurs in phonological form, it is assumed that the process of agreement will be influenced by other phonological factors such as syncretism, which will be discussed in this paper. Our goal is to determine the effect of morphophonological factors on the level of mental processes of the speakers of Serbian and to contribute to the existing knowledge and theories about agreement in Serbian through the application of contemporary methods.

The paper is organised as follows: the second section will briefly show the results of previous research and the relevant theoretical claims and define the methodology; the third section will contain the design, the results and the discussion of the elicited production experiment which tests the effects of the presence / the absence of syncretism on agreement; and the fourth section will discuss the design, the results and the experiments; the fifth chapter contains the conclusion.

\section{THEORETICAL BACKGROUND}

Previous corpus research (Maretić 1899; Corbett 1983) acknowledges resolved agreement as the most frequent pattern of agreement when a verb agrees with a pre-verbal coordinated subject consisting of conjuncts of different gender and number values. However, Bošković (2009), whose research is based on the introspective method, i.e. the author's own estimation, views resolved agreement as the only available pattern of agreement in the case of verb agreement with these kinds of coordinated conjuncts. He claims that agreement with one of the conjuncts of a coordinated subject with a first neutral gender singular conjunct and the last feminine gender plural conjunct is not possible for syntactic reasons. Namely, according to this author, agreement is a purely syntactic mechanism which consists of operations such as Probe, Match and Value and depends on the 
representation of features: interpretable and non-interpretable, valued and non-valued. As Bošković (2009) states, unless a verb agrees in terms of gender upon the first search which serves to find the agreement controller, a second search is bound to occur only if there are conditions for it. When a verb is in agreement with the coordinated subject consisting of conjuncts of different gender and number values, the conjunctional phrase which has a plural value and the first conjunct of the coordinated subject, which is in singular form, have different number values; thus, there is no gender agreement with the first conjunct upon the first search. Since the number marker of the first conjunct cannot be deleted because the number is interpretable, it is not possible to apply another operation which would enable agreement with the last conjunct. Accordingly, resolved agreement is the only available option. The question which will be examined in this paper is what occurs when a verb agrees with coordinated non-syncretic conjuncts of different gender and number values.

According to the approach by Marušič, Nevins, and Badecker (2015), agreement can be explained through an Agree-Copy and Agree-Link process, where linking occurs in syntax and copying in syntax and postsyntax. According to these authors, agreement with one of the conjuncts occurs due to separate searches for gender and number values, whereby the coordinated phrase with which the verb agrees is able to calculate the number value, but not the gender value. There are two possibilities when deciding on the gender controller: agreement in relation to hierarchical locality and agreement in relation to linear locality. According to these authors, the Consistency Principle is applied when appointing the controller for number and gender. According to this principle, the verb agrees only with one of the conjuncts of mixed gender which has the same number value as the number controller (Marušič, Nevins, and Badecker 2015, 25). If a verb agrees with a coordinated subject whose first conjunct is singular and the last one plural, the agreement with the first conjunct will not be possible due to the application of the Consistency Principle; the possible agreement patterns are then resolved agreement and agreement with the last plural conjunct - linear proximity enables agreement with this conjunct. Since these results suggest that agreement occurs in phonological form as well, the question whether the patterns of agreement will be influenced by other phonological factors such as syncretism is examined in this study.

\subsection{Questions, hypothesis, goals}

In this paper, we start with the fact that resolved agreement is a failed agreement and that it occurs when a verb fails to agree in gender with one of the conjuncts. Even though Bošković (2009) claims that agreement is not a morphosyntactical process and does not take into account the effects of morphosyntactical and morphophonological factors on agreement, we rely on the claim made by Marušič, Nevins, and Badecker (2015) about Slovenian, as well as that of Willer-Gold et al. (2016) about Serbian and Slovenian, which is that agreement is influenced by factors such as the linear order of elements. We assume that agreement will be influenced by other factors, such as syncretism. As the plural form of nominative case feminine gender nouns (škol-e) and the singular form of nominative case neutral gender nouns (polj-e) are syncretic, we assume that syncretism between conjuncts can affect gender agreement by decreasing the possibility of resolved agreement and increasing the possibility of the verb agreeing in gender with one of the conjuncts. The question is whether the presence of syncretism is able to increase the possibility of agreement with the plural conjunct (in our case the last conjunct) in relation 
to agreement with the non-syncretic subject. The hypothesis and the prediction of our research paper are the following:

Hypothesis 1: Agreement occurs in phonological form, i.e. the liner proximity of the last conjunct to the verb determines the last conjunct as the agreement controller.

Prediction: apart from linearity, other phonological factors such as syncretism affect the pattern of agreement by increasing the possibility of agreement with one of the conjuncts while decreasing the possibility of resolved agreement.

In order to test whether agreement is influenced by factors such as syncretism, we will compare agreement with syncretic and non-syncretic conjuncts presented in the order of the first conjunct being of neutral gender, singular and the last conjunct of feminine gender, plural. Hypothesis 1 and its prediction are tested by an elicited production experiment and acceptability judgment experiments. The same examples were used in both the elicited production experiment and the acceptability judgment experiments and neither of the experiments included the same participants. We conducted acceptability judgment experiments in order to verify the possible influence of choosing production as an experimental technique in the elicited production experiment.

Our goal is to answer the questions about a) whether agreement occurs in phonological form, and b) whether syncretism affects the choice between resolved agreement and agreement with the last plural conjunct.

\section{THE ELICITED PRODUCTION EXPERIMENT WHICH TESTS THE EFFECT OF THE PRESENCE OF SYNCRETISM ON GENDER AGREEMENT}

In this section we will first state the design, and then the results and the discussion of the elicited production experiment which tests the effect of syncretism on agreement. The experiment which tests the effect of the presence of syncretism on gender agreement is designed according to the methodology used by Willer-Gold et al. (2016) and was performed via the online portal Ibex Farm. The experiment is designed to verify the prediction for hypothesis (1), which states that the presence of syncretism decreases the possibility of resolved agreement, while the absence of syncretism increases it.

The experiment includes neutral gender singular nouns with the affix $-e$ (jaj-e) and affix $-o$ (pism-o), and feminine gender plural nouns with the affix $-e$ (map-e). We examined whether the examples containing neutral gender singular nouns with the affix $e$, with the same phonological form as feminine gender plural nouns, produce a greater percentage of the appearance of $-e$ on the verb along with the agreement with the last conjunct than the examples containing neutral gender nouns ending in $-o{ }^{1}$

\footnotetext{
${ }^{1}$ Considering that the conjuncts are syncretic and end in $-e$, the question is how one can know whether the verb ending $-e$ implies agreement with the last plural conjunct. As our previous research has shown, the evidence which supports the claim that the verb ending - $e$ is a definite result of plural conjunct agreement is the fact that the presence of syncretism in the Serbian language leans toward plural interpretation.
} 


\subsection{The elicited production experiment testing the effect of the presence of syncretism on gender agreement: design}

In this paper we comment on the two conditions (as in examples 1 and 2 below) from the experiment which tests the effect of the presence of syncretism on agreement. ${ }^{2}$ Every condition is tested with 6 examples, thus making the total number of critical examples $12 .^{3}$ Substitute subjects were disyllabic inanimate nouns of approximately equal frequent use in contemporary Serbian language, excerpted from the Serbian Language Dictionary (SLD 2007), the Reverse Index Dictionary of the Serbian Language (Nikolic 2000) and from the Lexical frequency corpus of contemporary Serbian language (Arsenijević 2015).

All the model sentences, substitute subjects and targeted expressions were equable in the number of characters, so as to neutralise the effect the length of the example could have on the choice of the pattern of agreement (the average number of characters for every condition is listed, see examples 1 and 2).

1. The condition with the presence of syncretism in the coordinated subject with a first neutral gender, singular conjunct, ending in $-e$, and a second feminine gender, plural conjunct, ending in $-e$ (model sentence: 21 ; coordinated subject: 11 ; targeted expression: $28,5)$

$\begin{array}{clll}\text { Model sentence: } \text { Ručak } & \text { je } & \text { pojeden } & \text { na brzinu. (22) } \\ \text { lunch.MSg } & \text { Aux.Sg } & \text { eaten.MSg } & \text { in rush }\end{array}$

'The lunch was eaten in a rush'.

\begin{tabular}{|c|c|c|c|c|}
\hline $\begin{aligned} \text { Coordinated subject: } & \text { Jaje } \\
& \text { egg.NSg }\end{aligned}$ & $\begin{array}{l}i \\
\text { al }\end{array}$ & $\begin{array}{l}\text { šljive } \\
\text { plum }\end{array}$ & & \\
\hline $\begin{array}{l}\text { Targeted expression: Jaje } \\
\text { egg.NSg }\end{array}$ & $\begin{array}{l}i \\
\text { and }\end{array}$ & $\begin{array}{l}\text { šljive } \\
\text { plums.FPl }\end{array}$ & $\begin{array}{l}s u \\
\text { Aux.Pl }\end{array}$ & $\begin{array}{l}\text { pojedeni/ pojedene/ } \\
\text { eaten.MPI/FP1 }\end{array}$ \\
\hline $\begin{array}{l}j e \\
\text { Aux.Sg }\end{array}$ & $\begin{array}{l}\text { deno } \\
\text { n.NSg }\end{array}$ & $\begin{array}{l}n a b \\
\text { on rt }\end{array}$ & $u(28)$ & \\
\hline
\end{tabular}

'The egg and the plums were eaten in a rush'.

2. The condition without the presence of syncretism in the coordinated subject with a first neutral gender, singular conjunct, ending in $-o$, and a second feminine gender, plural conjunct, ending in $-e$ (model sentence: 21 ; coordinated subject: 11 ; targeted expression: 28,3);
Model sentence: Dokaz
je
ukraden
iz torbe (21)
evidence.MPl
Aux.Sg
stolen.Msg
from bag.

'The evidence was stolen from the bag'.

\footnotetext{
2 The detailed description of the design is given in the link http://filum.kg.ac.rs/dokumenta/arhiva/ Doktorska_disertacija_Ivane_Mitic.pdf.

${ }^{3}$ There is an equal number of critical examples and fillers in the experiment. Fillers are implemented to avoid the possibility of a) the participants realising what the experiment is about and b) the participants becoming tired of only one type of task in the experiment.
} 


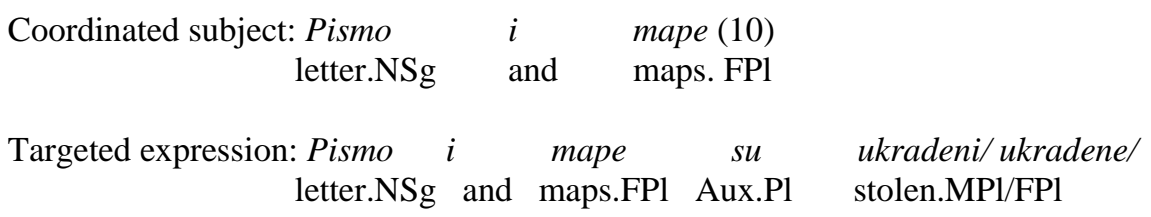

$\begin{array}{lll}\text { je } & \text { ukradeno } & \text { iz torbe (27). } \\ \text { Aux.Sg } & \text { stolen.NSg } & \text { from bag }\end{array}$

'The letter and the maps were stolen from the bag'.

The experiment contains one independent variable with two levels - level one is the absence of syncretism, level two is the presence of syncretism - and one dependent variable. The dependent variable in this experiment is the pattern of agreement - agreement with the first conjunct (FCA), agreement with the last conjunct (LCA) and resolved agreement (RES). Our goal is to determine whether a greater percentage of a verb ending in the affix $-e$ occurs with the presence or absence of syncretism. These results will be compared with the answers containing resolved agreement.

The procedure for the elicited production experiment is as follows: the participants first see the model sentence on the computer screen and read it out loud (as in example 3). Every model sentence contains a masculine gender noun with which the verb agrees and which is displayed in bold font. The model sentence disappears from the screen by pressing the zero key, after which a substitute subject is displayed (as in example 4). The participants' task is to replace the bold part from the model sentence with the substitute subject, then to adapt the verb from the model sentence to the substitute subject and read the new sentence (as in example 5 where the possible answers are listed). All answers were recorded in the audio recording program Audacity (in wav. format) and then coded as RES (resolved agreement), LIN (gender agreement with the last conjunct of the pre-verbal coordinated subject), and FCA (gender agreement with the first conjunct of the pre-verbal coordinated subject). These abbreviations will be used in the paper. The experiment included 36 participants.

\section{Model sentence: Dokaz je ukraden iz torbe. evidence.MSg Aux.Sg stolen.MSg from bag}

'The evidence was stolen from the bag'.

4. Substitute subject: Pismo $i \quad$ mape

letter.NSg and maps.FPl

5. Targeted expression: Pismo $i$ mape su ukradeni/ letter.NSg and maps.FPl Aux.Pl stolen.MPl

$\begin{array}{llll}\text { lukradene } & \text { /je } & \text { ukradeno } & \text { iz torbe. } \\ \text { stolen.FPl } & \text { Aux.Sg } & \text { stolen.NPl } & \text { from bag }\end{array}$

'The letter and the maps were stolen from the bag'. 


\subsection{The elicited production experiment which tests the effect of the presence of syncretism on gender agreement: results}

As the results show, resolved agreement is the most frequently used pattern of agreement in this experiment (for condition $\mathrm{NSg}(\mathrm{o}) \mathrm{FPl} \mathrm{RES}=80,5 \%$, for condition $\mathrm{NSg}(\mathrm{e}) \mathrm{FPl} \mathrm{RES}=63 \%$ ). The last conjunct agreement, the so-called linear agreement, is a documented and stable pattern of agreement (for condition NSg(e)FPl LIN=36\%, and for condition $\mathrm{NSg}(\mathrm{o}) \mathrm{FPl} \mathrm{LIN}=15 \%)$. The experiment does not confirm the pattern in which the verb agrees with the first conjunct.

In order to establish whether there is a significant statistical difference in the use of the patterns of agreement in relation to the tested conditions, we implemented a $\chi^{2}$ test. The $\chi^{2}$ test shows the existence of a statistically significant difference when it comes to the mode in which the presence of syncretism affects the use of the patterns of agreement $\chi 2(2, \mathrm{~N}=421)=22,79, \mathrm{p}<0,00001$. Resolved agreement is significantly less frequently produced with the absence of syncretism, whereas the pattern in which the verb agrees with the last conjunct is more frequent when syncretism is present.

We also implemented a z-test, results of which will be briefly shown here and addressed in detail in the Discussion. The comparison of the percentage number for the last conjunct agreement in the 'presence of syncretism' subsample and the percentage number for this pattern in the 'absence of syncretism' subsample shows a statistically significant difference $(\mathrm{p}<0,001, \mathrm{Z}=4,5)$. There is also a statistically significant difference when we compare the percentage number for resolved agreement in the "presence of syncretism' subsample and the percentage number for resolved agreement in the 'absence of syncretism' subsample ( $\mathrm{p}<0,03, \mathrm{a} Z=-2,2)$.

\subsection{The elicited production experiment which tests the effect of the presence of syncretism on gender agreement: discussion}

Through the implementation of the elicited production experiment we verified the validity of hypothesis (1) which states that agreement occurs in the phonological form as well. This hypothesis is verified through the prediction which states that the presence of syncretism decreases the possibility of resolved agreement and increases the possibility of the last conjunct agreement, while the absence of syncretism has the reverse effect. As the results indicate, the last conjunct agreement is more frequently used when syncretism is present, which is in supports the hypothesis (1) prediction ( $\mathrm{LIN}=36 \%$ for condition $\mathrm{NSg}(\mathrm{e}) \mathrm{FPl}$, and $15 \%$ for $\mathrm{NSg}(\mathrm{o}) \mathrm{FPl}, \mathrm{p}<0,001, \mathrm{Z}=4,5)$. Resolved agreement is significantly less frequently used with the presence of syncretism, which confirms the prediction of hypothesis (1) $(\mathrm{NSg}(\mathrm{e}) \mathrm{FPl}=80,5 \%$, and for $\mathrm{NSg}(\mathrm{o}) \mathrm{FPl}=63 \%$, the $z$ test confirmed a significant difference, $\mathrm{p}<0,03)$.

\section{ACCEPTABILITY JUdGMENT EXPERIMENTS WHOSE CONDITIONS CORRESPOND WITH THE ELICITED PRODUCTION EXPERIMENT}

The acceptability judgment experiments the conditions of which correspond to the previously mentioned elicited production experiment test the prediction of hypothesis (1) which states that the presence of syncretism decreases the degree of acceptability of resolved agreement and increases the degree of acceptability of the last conjunct agreement, while the absence of syncretism has the reverse effect. 


\subsection{Acceptability judgment experiments whose conditions correspond with the elicited production experiment: design}

Acceptability judgment experiments the conditions of which correspond to the elicited production experiment contain 2 conditions (as in examples 6-7a) ${ }^{4}$. Since the examples are organised into 6 lists for the sake of balance, and two examples for each of the conditions within these 6 lists were seen by 8 participants, there are 96 observations for each acceptability judgment condition. The first two examples for every condition in the elicited production experiment were incorporated in the acceptability judgment experiment by having the verb agree with the first conjunct. The second two examples for every condition in the elicited production experiment were incorporated in the acceptability judgment experiment so that the verb agreed with the conjunctional phrase, and the third pair of examples for every condition in the elicited production experiment were incorporated in the acceptability judgment experiment so that the verb agreed with the last conjunct (as in examples 6 and 7a). The critical stimuli in the acceptability judgment experiments tested the acceptability of agreement patterns of the verb with coordinated subjects in pre-verbal conditions.

6. $\mathrm{NSg}(\mathrm{e}) \mathrm{FPl}$ FCA/RES/LIN

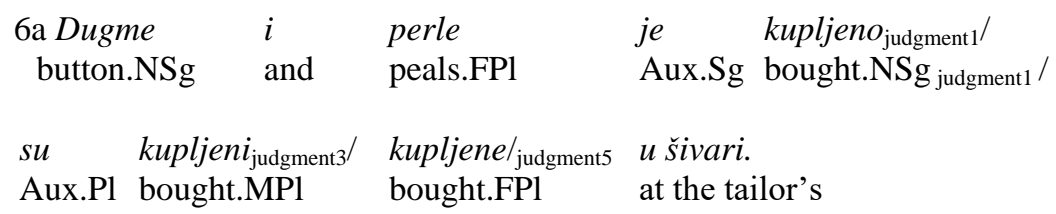

'The button and the peals were bought at the tailor's'.

7. $\mathrm{NSg}(\mathrm{o}) \mathrm{FPl}$ FCA/RES/LIN

\begin{tabular}{|c|c|c|c|c|}
\hline $\begin{array}{l}\text { 7a Pismo } \\
\text { letter.NSg }\end{array}$ & $\begin{array}{l}i \\
\text { and }\end{array}$ & $\begin{array}{l}\text { mape } \\
\text { maps.FPl }\end{array}$ & $\begin{array}{l}\text { je } \\
\text { Aux.Sg }\end{array}$ & $\begin{array}{l}\text { ukradeno }_{\text {judgment } 1} / \\
\text { stolen.NSg }\end{array}$ \\
\hline $\begin{array}{l}s u \\
\text { Aux.Pl }\end{array}$ & $\begin{array}{l}\text { ukrade } \\
\text { stolen }\end{array}$ & $\begin{array}{l}\text { dgment3 } / \\
\mathrm{l}_{\text {judgment } 3} /\end{array}$ & $\begin{array}{l}\text { ukradene/ } \text { judgment5 }_{\text {knd }} \\
\text { stolen.FPl } \\
\text { judgment5 }\end{array}$ & $\begin{array}{l}\text { iz torbe. } \\
\text { from bag }\end{array}$ \\
\hline
\end{tabular}

'The letter and the maps were stolen from the bag'.

The examples are randomised and the randomisation was completed through the online portal Ibex Farm. The procedure for the acceptability judgment experiment is as follows: the participant first sees the example (as in example 8), clicks the zero key, and then the rating numbers from 1 to 5 appear on the screen (as in example 9). The participants' task is to rate the acceptability of the examples on a 5-point Likert Scale (1 absolutely unnatural

\footnotetext{
${ }^{4}$ The label: judgment $1 / 2 / 3 / 4 / 5 / 6 /$ is put after each pattern of agreement within every example to signify the acceptability judgment experiment for which the degree of acceptability of the example in relation to said pattern of agreement was tested.

${ }_{5}^{5}$ The acceptability judgment experiment contains an equal number of critical stimuli and fillers. A detailed design of the fillers and critical examples is given in the link http://filum.kg.ac.rs/dokumenta/arhiva/Doktorska disertacija_Ivane_Mitic.pdf.
} 
and unacceptable, 5 absolutely natural and acceptable). The response time is limited to $3500 \mathrm{~ms}$, after which time the example disappears from the screen. The participant is instructed to proceed to the next example and is told that the experiment is finished when the words "Results successfully sent to the server" appear on the screen.

Forty eight participants completed the acceptability judgment experiments. All of the participants are native speakers of Serbian, and students at the University in Niš. They had not had any explicit linguistic education before the experiment and had not participated in the elicited production experiment previously mentioned.
8. Dugme button.NS $i$ perle su kupljeni $i_{\text {judgment } 3} /$ $u$ šivari. at tailor's

'The button and the pearls were bought judgment $3 /$ at the tailor's'.
9. 1
2
3
4
5

The acceptability judgment experiments contain the following independent variables:

1) The pattern of agreement (three levels: first conjunct agreement, last conjunct agreement and resolved agreement);

2) The presence and absence of syncretism.

The dependent variable is the degree of acceptability (from 1 to 5).

\subsection{Acceptability judgment experiments whose conditions correspond with the elicited production experiment: results}

Based on the degree of acceptability with which the native speakers of the Serbian rated the tested examples, we calculated the mean, which is explained further in the text. First conjunct agreement was rated with the lowest number, regardless of the presence $\mathrm{NSg}(\mathrm{e}) \mathrm{FPl}=1,6$, or absence of syncretism $\mathrm{NSg}(\mathrm{o}) \mathrm{FPl}=1,7$. The degree for resolved agreement is lower for the condition $\mathrm{NSg}(\mathrm{e}) \mathrm{FPIRES}=3,3$ that the degree for the condition $\mathrm{NSg}(\mathrm{o}) \mathrm{FPIRES}=3,9$. The last conjunct agreement was rated to a similar degree for both conditions $\mathrm{NSg}(\mathrm{o}) \mathrm{FPILIN}=3,2$ and $\mathrm{NSg}(\mathrm{e}) \mathrm{FPILIN}=3,1$.

With the implementation of a two-way ANOVA with replication we examined the interaction between the tested conditions and the degrees of acceptability of the patterns of agreement. We compared two factors with two levels respectively (Table 1). The first level of the first factor is the presence of syncretism, and the second the absence of syncretism ( $\mathrm{NSg}(\mathrm{e}) \mathrm{FPl}$ and $\mathrm{NSg}(\mathrm{o}) \mathrm{FPl})$. The second factor is the pattern of agreement, which included three combinations: 1) level one is the pattern of resolved agreement, and level two is the pattern of first conjunct agreement; 2) level one is the pattern of resolved agreement, level two is the pattern of last conjunct agreement; 3) level one is the pattern of first conjunct agreement, and level two is the pattern of last conjunct agreement. Table 1 (1) shows the difference between $\mathrm{NSg}(\mathrm{o}) \mathrm{FPl}$ and $\mathrm{NSg}(\mathrm{e}) \mathrm{FPl}$; (2) between resolved and hierarchical (RES:FCA), resolved and linear (RES:LIN) and linear and hierarchical agreement (LIN:FCA), and (3) shows whether there is interaction. The results will be discussed in the Discussion. 
Table 1 The Results of the two-way ANOVA with replication for the conditions corresponding with the elicited production experiment

\begin{tabular}{ll}
\hline & $\mathrm{NSg}(\mathrm{o}) \mathrm{FP} 1: \mathrm{NSg}(\mathrm{e}) \mathrm{FP} 1$ \\
\hline RES : FCA & 1. $<<0,03, \mathrm{~F}=4,8$ \\
& 2. $\mathrm{p}<0,0001$, a F=220 \\
& 3. $<<0,04, \mathrm{~F}=4,04$ \\
RES : LIN & 1. $<<0,04, \mathrm{~F}=4,04$ \\
& 2. $<<0,005$, a F=8 \\
FCA : LIN & 3. No interaction \\
& 1. No difference \\
& 2. $<<0,001$, a F=129; \\
& 3. No interaction \\
\hline
\end{tabular}

\subsection{Acceptability judgment experiments whose conditions correspond with the elicited production experiment: discussion}

The acceptability judgment experiments whose conditions correspond to the elicited production experiment described above were conducted in order to test hypothesis (1), which states that agreement occurs in the phonological form. The prediction of this hypothesis is that the presence of syncretism will increase the degree of acceptability of last conjunct agreement, and decrease the degree of acceptability of resolved agreement, while the absence of syncretism will have the reverse effect. Our results show that the degree of acceptability for resolved agreement is higher than the degree of acceptability for linear agreement for both conditions (Table 1 shows that the difference is confirmed statistically). Additionally, the results point out that the presence of syncretism has a degrading effect on the frequency of resolved agreement, which confirms the prediction of hypothesis (1) (comp. NSg(e)FPIRES=3,3 and NSg(o)FPIRES=3,9; see Table 1 which shows the existence of a significant difference). As for last conjunct agreement, this pattern was rated to a similarly high degree both in the presence $(\mathrm{NSg}(\mathrm{e}) \mathrm{FPl}=3,1)$ and the absence $(\mathrm{NSg}(\mathrm{o}) \mathrm{FPl}=3,2)$ of syncretism. The first conjunct agreement received low rates, regardless of the presence or absence of syncretism $(\mathrm{NSg}(\mathrm{e}) \mathrm{FPl}=1,6$ and $\mathrm{NSg}(\mathrm{o}) \mathrm{FPl}=1,7)$. Since there is a significant difference between the degree of acceptability for first conjunct agreement and the degree of acceptability for last conjunct agreement, we assume that syncretism leans toward plural interpretation (Table 1 shows that the difference is statistically significant). This confirms hypothesis (1).

\section{CONCLUSION}

In the present study, by conducting an elicited production experiment and the acceptability judgment experiments, we have tested the prediction of hypothesis (1), which states that agreement occurs in the phonological form as well. As evident from our results, the sequence of the patterns of agreement in the elicited production experiment and acceptability judgment experiments shows the same image: resolved agreement is the pattern of agreement rated to the highest degree in the acceptability judgment experiment and it is the one most frequently used in the elicited production experiment; and agreement with the last plural conjunct was rated as a completely acceptable form of agreement in the acceptability judgment experiment and a solid percentage number was 
documented in the production experiment. The results of both the acceptability judgment experiments and the elicited production experiment confirm hypothesis (1) that the acceptability of resolved agreement will be rated to a low degree and that this pattern will have been documented with a lower percentage number when there is syncretism, than when there is none. Considering that last conjunct agreement has received similar ratings in the acceptability judgment experiments and that its production is twice reduced in the absence of syncretism, we assume that there is a difference between the production and the perception of this pattern, which would mean that a part of the image in the production depends on production performance. The results of both experiments confirm our prediction that agreement occurs in the phonological form as well.

Acknowledgement: The paper is part of the project The Serbian language then and now: linguistic research (no. 360/1-16-10-01), organized by the Faculty of Philosophy in Niš, and the project Spoken and standard language in public communication in Niš, (no. O-25-20), developed by the SASA branch in Niš. This study was financed by the Serbian Ministry of Education, Science and technological development.

\section{REFERENCES}

Bošković, Željko. 2009. "Unifying first and last conjunct agreement." Natural Language and Linguist Theory, 27(3): 455-496.

Corbett, Greville. 1983. "Slaganje predikata sa više subjekata u srpskom jeziku." Naučni sastanak slavista u Vukove dane, 12: 93-103.

Maretić, Tomo. 1899. Gramatika hrvatskoga ili srpskoga književnog jezika. Zagreb: Matica hrvatska.

Marušič, Franc, Nevins Andrew and William Badecker. 2015. "The grammars of conjunction agreement in Slovenian.” Syntax, 18(1): 39-77.

Mitić, Ivana. 2019. Efekat gramatičkih i semantičkih karakteristika koordiniranih subjekata na slaganje glagola u rodu u srpskom jeziku. In Serbian. Unpublished doctoral dissertation. University of Kragujevac, Faculty of Philology and Arts. http://filum.kg.ac.rs/dokumenta/arhiva/Doktorska_disertacija_Ivane_Mitic.pdf

Willer-Gold, Jana, Boban Arsenijević, Mia Batinić, Nermina Čordalija, Marijana Kresić, Nedžad Leko, Franc Marušič, Tanja Milićev, Nataša Milićević, Ivana Mitić, Andrew Nevins, Anita Peti-Stantić, Branimir Stanković, Tina Šuligoj, and Jelena Tušek. 2016. "Conjunct Agreement and Gender in South Slavic: From Theory to Experiments to Theory." Journal of Slavic Linguistics, Special Issue Agreement in Slavic, 24(1): $187-225$.

\section{RESOURCES}

Arsenijević, Boban. 2015. Leksičko-frekvencijski rečnik savremenog srpskog jezika. Niš: Filozofski fakultet u Nišu. Nikolić, Miroslav. 2000. Obratni rečnik srpskog jezika. Novi Sad: Matica srpska, Beograd: Institut za srpski jezik. Nikolić, Miroslav (ed.). 2007. Rečnik srpskog jezika. Novi Sad: Matica srpska. 


\section{SLAGANJE GLAGOLA SA PREVERBALNIM KOORDINIRANIM (NE)SINKRETIČNIM SUBJEKTOM}

U ovom radu se ispituju efekti koji doprinose da se glagol složi sa samo jednim od koordiniranih članova različitog roda i broja nasuprot razrešenom slaganju. Dosadašnja istraživanja na materijalu korpusa (Maretić 1899, Corbett 1983) pokazuju da je razrešeno slaganje najfrekventniji obrazac slaganja kada se glagol slaže sa preverbalnim koordiniranim članovima različitog roda i broja. Bošković (2009) pak tvrdi da je razrešeno slaganje jedini dostupan obrazac slaganja, te da se glagol ne može složiti sa samo jednim od članova mešovitog koordiniranog subjekta iz sintaksičkih razloga. Novija eksperimentalna istraživanja na materijalu slovenačkog jezika (Marušič, Nevins, and Badecker 2015) potvrđuju da se glagol može složiti i sa članom koji je u množini. Ovi autori za slovenački $i$ Willer Gold $i$ dr. (2016) između ostalog $i$ za srpski jezik pokazuju da se slaganje dešava $i$ na interfejsu sa fonologijom. U ovom radu, produkcijskim eksperimentom i eksperimentima sa sudovima gramatičnosti provereno je šta se dešava kada se glagol slaže sa preverbalnim koordiniranim (ne)sinkretičnim konjunktima različitog roda i broja. Rezultati pokazuju da je razrešeno slaganje statistički značajno manje upotrebljeno kada se glagol slaže sa koordiniranim sinkretičnim nego sa nesinkretičnim subjektom, kao i da je slaganje sa poslednjim množinskim članom dostupan $i$ validan obrazac slaganja bez obzira na to da li su članovi (ne)sinkretični. Rezultati idu u prilog hipotezi da se slaganje vrši i na interfejsu sa fonologijom.

Ključne reči: kongruencija, koordinirani subjekat, gramatički rod i gramatički broj, sinkretizam, linearna bliskost. 